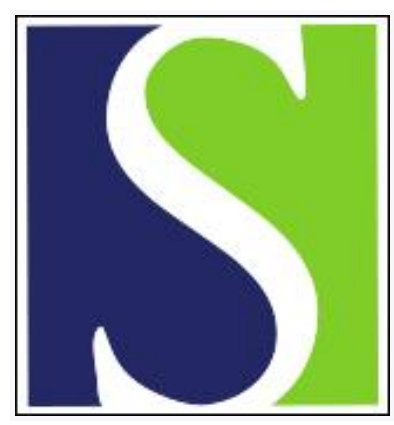

Scand J Work Environ Health 1988;14(6):378-384

https://doi.org/10.5271/sjweh.1903

Issue date: Dec 1988

Health effects due to occupational exposure to cobalt blue dye among plate painters in a porcelain factory in Denmark.

by Raffn E, Mikkelsen S, Altman DG, Christensen JM, Groth S

Affiliation: Department of Occupational Medicine, Danish Labour Inspectorate, Copenhagen, Denmark.

The following article refers to this text: 1989;15(4):245-264

This article in PubMed: www.ncbi.nlm.nih.gov/pubmed/3264937 


\title{
Health effects due to occupational exposure to cobalt blue dye among plate painters in a porcelain factory in Denmark
}

\author{
by Edith Raffn, MD, ${ }^{1}$ Sigurd Mikkelsen, DrMedSc, ${ }^{2}$ Douglas G Altman, MSc, ${ }^{3}$ \\ Jytte M Christensen, MSc, ${ }^{4}$ Steffen Groth, MD ${ }^{5}$
}

\begin{abstract}
RAFFN E, MIKKELSEN S, ALTMAN DG, CHRISTENSEN JM, GROTH S. Health effects due to occupational exposure to cobalt blue dye among plate painters in a porcelain factory in Denmark. Scand $J$ Work Environ Health 14 (1988) 378-384. Forty-six plate painters, heavily exposed to cobalt blue dye, took part in this cross-sectional study, and 51 top-glaze painters served as the referents. The study comprised a questionnaire, a health examination, a lung function test, and the determination of the blood and urinary cobalt levels. The plate painters were examined twice, at the end of a workfree period and after resuming work. More plate painters complained of irritation from the mucous membranes in the mouth and throat, cough, and expectoration than the referents. The symptoms increased after the plate painters resumed work. The cobalt level of the plate-painting group after six weeks off work was twice as high in the blood and five times higher in the urine than the corresponding values of the reference group. After the plate painters resumed work, the blood and urinary levels increased approximately 4 and 15 times, respectively. Increased airflow resistance was found in the plate group when compared with the referents, and signs of small airway obstruction increased after the plate painters resumed work. The pulse rate was higher among the plate painters, and minor changes in the red blood cell picture were observed. None of these adverse health effects were associated with the cobalt levels in the blood or urine.
\end{abstract}

Key terms: cobalt, cross-sectional study, electrocardiogram, lung function, plate painting, red blood cell picture.

Adverse health effects following cobalt exposure in the porcelain industry have not been described previously in the literature, with the exception of one study concerning an occupational skin condition in a pottery (15). Inhalation of cobalt dust in the hard metal industry may cause several adverse health effects, eg, asthma, fibrosing alveolitis, and, very occasionally, diffuse interstitial pulmonary fibrosis, ie, "hard metal disease" (12). The intake of cobalt salts may cause systemic poisoning (21).

Since 1888 a Danish porcelain factory has produced porcelain plates by a special technique: underglazing (with cobalt blue color) especially developed to withstand the intense heat of the second porcelain firing (22). The cobalt blue underglaze color is made by melting together a mixture of metal salts, of which the most important are zinc oxide, cobalt zinc silicate, and silicon oxide. After the amorphous glass material is pulverized, the powder is mixed together with kaolin, hallosite, borax, glycerine, and water. Each plate is spray-

I Department of Occupational Medicine, Danish Labour Inspectorate, Copenhagen, Denmark.

2 Clinic of Occupational Medicine, Rigshospitalet, Copenhagen, Denmark.

3 Statistical Research Unit, Panum Institute, Copenhagen, Denmark, and Clinical Research Centre, Harrow, Middelsex, England.

4 Danish National Institute of Occupational Health, Copenhagen, Denmark.

s Department of Physiology, Finsen Institute, Copenhagen, Denmark.

Reprint requests to: Dr E Raffn, Herlufsholmvej 37, DK 2720 Vanløse, Denmark. painted two or three times with the water-based cobalt blue underglaze. After each painting procedure, the plates are allowed to dry, and the excess color is removed with a brush. The plate painting is carried out in a fume extraction cupboard.

In 1981, the plate painters complained of such workrelated symptoms as irritation of the upper respiratory tract, cough and expectoration to the point that the factory organized measurements in the work area of the exposure to cobalt, silica, nickel, and dust. The results of 19 personal samples with $3 \mathrm{~h}$ of sampling time showed a median cobalt concentration of 0.80 (range $0.068-8.61) \mathrm{mg} / \mathrm{m}^{3}$ in the air. The Danish occupational exposure limit is $0.05 \mathrm{mg} / \mathrm{m}^{3}$. There was no detectable concentration of silica, and that of nickel was lower than $10 \%$ of the Danish occupational exposure limit $\left(0.1 \mathrm{mg} / \mathrm{m}^{3}\right)$. Five measurements of respirable dust showed values of $3.6,5.5,10.6,7.7$, and $10.6 \mathrm{mg} / \mathrm{m}^{3}$.

These findings of very high levels of cobalt in the work area, together with the complaints of workrelated symptoms among the plate painters, gave rise to concern about possible adverse health effects from cobalt exposure, and finally the factory requested the Clinic of Occupational Medicine, Rigshospitalet, Copenhagen to investigate the problem.

\section{Subjects and methods}

The study is a cross-sectional study of the plate painters with a group of top-glaze painters without cobalt ex- 
posure as the reference group. All the subjects were women.

Within the porcelain factory 49 plate painters were exposed to cobalt blue dye. One did not wish to participate, and two were sick. In the group of 58 topglaze painters, two were sick and five did not wish to participate. Thus the study population comprised 46 exposed and 51 unexposed women. The mean age of the plate painters was 39.3 (SD 9.6) years, and that of the referents 39.6 (SD 9.0) years. The mean height of the plate painters was 164.8 (SD 6.5) $\mathrm{cm}$, and that of the referents 164.2 (SD 6.5) $\mathrm{cm}$. The mean weight of plate painters was 61.3 (SD 10.3) kg, and that of the referents 60.0 (SD 8.4) kg. The mean duration of employment was 11 (range 2-25) years for the plate painters and 14 (range 2-31) years for the top-glaze painters. The two groups differed with respect to smoking. Of the plate painters $34(67 \%)$ were smokers, whereas only $15(29 \%)$ of the referents smoked.

The study took place from January to May 1982. Because of a seasonal interruption in production, the plate department was closed from the middle of December 1981 to the end of January 1982 and the plate painters were out of work during this period. Therefore the opportunity was taken to study these workers with and without acute exposure to cobalt. The plate painters were examined twice, once at the end of the workfree period and a few weeks after they resumed work. The referents were examined only once. The examination program was the same for all the examinations.

All the participants filled out a standard questionnaire of the Clinic of Occupational Medicine. The questionnaire comprises 186 questions about health, work conditions, length of employment, life-style, and social conditions.

The health examination included inspection of the skin and mucosa of the eyes, mouth and throat, palpation of the thyroid gland, auscultation of the heart and lungs, and measurements of blood pressure. A 12-lead electrocardiogram was taken and interpreted according to the Minnesota standard (1). Blood samples were taken for the determination of cobalt, hemoglobin, erythrocytes, hematocrit, the mean cell hemoglobin concentration, and the mean cell volume, and urine samples were analyzed for cobalt and creatinine. The urine samples were also examined for blood, protein, and glucose. All the urine cobalt results were adjusted to their creatinine concentration.

Blood was collected in acid-washed vacutainer tubes for the determination of cobalt. To prevent contamination, strict guidelines on cleaning were adhered to. The skin was washed with a $2 \%$ ethylenediaminetetraacetate (EDTA) solution before desinfection with alcohol, and the cannula was flushed with blood before the blood was collected for the cobalt analysis. The urine was collected directly into acid-washed polyethylene bottles. The blood and urine samples were stored at $-80^{\circ} \mathrm{C}$ until the analyses. The creatinine concen- trations in the urine were determined by the Jaffe reaction with a Beckman 42 spectrophotometer.

The cobalt concentration of the blood and urine was analyzed with a Zeeman atomic absorption spectrophotometer (11). The detection limit was 1.70 $\mathrm{nmol} / \mathrm{l}$. The between-run coefficient of variation was $5.3 \%$.

Blood and urine samples from the unexposed and exposed workers were analyzed independently by anodic stripping voltametry after wet digestion (18). The results showed good agreement.

All the investigations except the lung function tests were conducted at the factory.

The lung function tests were performed on computerized Jaeger equipment. The following variables were measured: vital capacity, residual volume, total lung capacity, peak expiratory flow (PEF), forced expiratory volume in $1 \mathrm{~s}\left(\mathrm{FEF}_{1.0}\right)$, forced expiratory flow rate at $25 \%$ and $50 \%$ of the vital capacity $\left(\mathrm{MEF}_{25}\right.$ and $\mathrm{MEF}_{50}$, respectively), nitrogen washout volume, closing volume, slope index, and transfer factor. The execution of the different lung function tests and the calculation of the results were performed according to the recommendations of the European Community for Coal and Steel (19). The lung function tests were performed before and $1 \mathrm{~h}$ after the inhalation of two puffs from a salbutamol canister.

\section{Statistical methods}

The distributions of the lung function variables were determined by the Shapiro-Wilk W test. Log transformations were applied to a few skewed variables to transform their distribution to an approximately normal one. Comparisons between the characteristics of the two groups were made with two-sample t-tests and chi-squared tests with Yates' correction. Multiple regression was used to compare the lung function measurements of the two groups after adjustment for age, height, and smoking. Smoking was treated as a binary variable with ex-smokers (8 out of 97) treated as nonsmokers. The effect of plate painting was found to be different between the smokers and nonsmokers for some variables, and an interaction term was incorporated into the model. The same model was used for all the lung function measurements. The addition of blood or urinary cobalt (logarithmic scale) or duration of employment to this model did not significantly improve the results for any lung function variable $(P>0.1)$. Paired t-tests were used to assess the changes between the two examinations for the exposed group. All P-values refer to tests in a two-tailed distribution.

\section{Results}

\section{Questionnaire}

The results of the questionnaire showed that the plate painters complained significantly more than the top- 
glaze painters of itching skin, irritation of the nose, mouth and throat, and of cough and expectoration. Furthermore, the plate painters reported more dyspnea during work and on exertion. The mucous membrane symptoms increased after the plate painters resumed work. There was no difference between the two groups concerning symptoms of bronchitis, but $11 \%$ of the plate painters complained of asthma-like symptoms compared with only $2 \%$ of the reference group.
This difference was not significant however $(P=0.09)$. There was no difference between the two groups with regard to symptoms from the other organ systems.

\section{Cobalt in blood and urine}

The concentrations of cobalt in three blood samples and six urine samples from the reference group were below the detection limit of $1.70 \mathrm{nmol} / \mathrm{l}$. These results
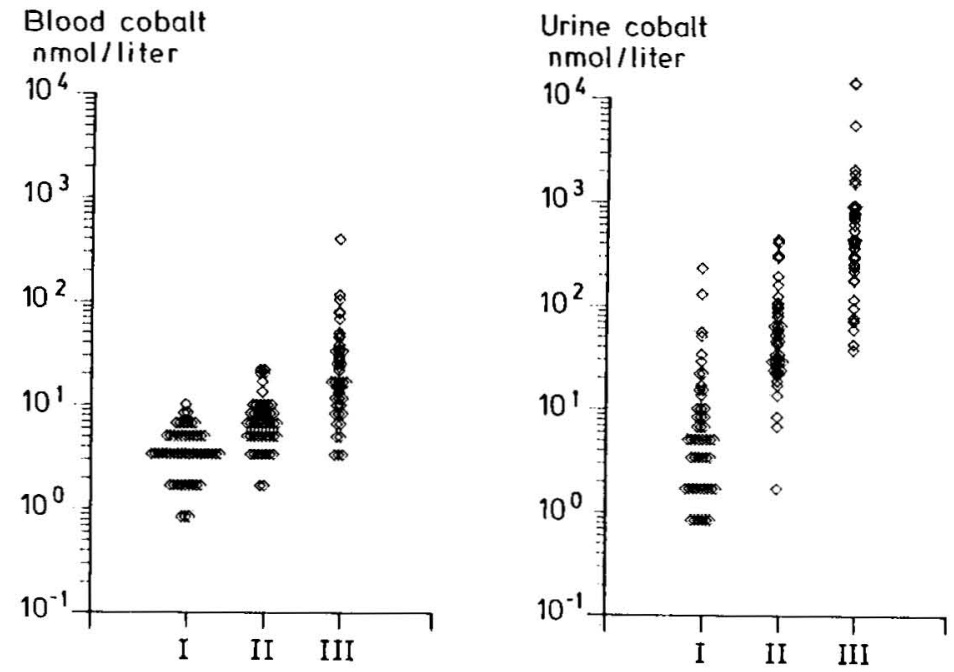

Figure 1. Blood and urine cobalt concentrations of the reference group (I), the plate painters after approximately six weeks off work (II), and the plate painters approximately four weeks after resuming work (III).

Table 1. Cobalt concentrations in the blood and urine of the study groups.

\begin{tabular}{|c|c|c|c|c|c|c|c|c|c|}
\hline \multirow{2}{*}{ Group } & \multicolumn{3}{|c|}{ Blood $(\mathrm{nmol} / \mathrm{l})$} & \multicolumn{3}{|c|}{ Urine (nmol/l) } & \multicolumn{3}{|c|}{$\begin{array}{c}\text { Urine } \\
\text { (nmol/mmol creatinine) }\end{array}$} \\
\hline & Mean & SD & Range & Mean & SD & Range & Mean & SD & Range \\
\hline Referents & 4.04 & 2.11 & $.^{a}-10.2$ & 16.0 & 37.8 & $a-234$ & 1.53 & 3.08 & ${ }^{a}-20.6$ \\
\hline \multicolumn{10}{|l|}{ Plate painters } \\
\hline $\begin{array}{l}\text { First examination }{ }^{\mathrm{b}} \\
\text { Second examination }^{\mathrm{c}}\end{array}$ & $\begin{array}{l}8.05 \\
36.7\end{array}$ & $\begin{array}{l}5.08 \\
63.2\end{array}$ & $\begin{array}{l}1.70-22.1 \\
3.40-407\end{array}$ & $\begin{array}{r}81.6 \\
1308\end{array}$ & $\begin{array}{r}101 \\
3005\end{array}$ & $\begin{array}{c}a-445 \\
37.4-14397\end{array}$ & $\begin{array}{r}8.82 \\
141.8\end{array}$ & $\begin{array}{l}123 \\
434\end{array}$ & $\begin{array}{c}.^{2}-65.2 \\
4.04-2776\end{array}$ \\
\hline
\end{tabular}

a Minimum cobalt concentration below the detection limit of $1.70 \mathrm{nmol} / \mathrm{l}$.

b The first examination took place after the workers had been off work for approximately six weeks.

c The second examination took place approximately four weeks after the workers resumed work.

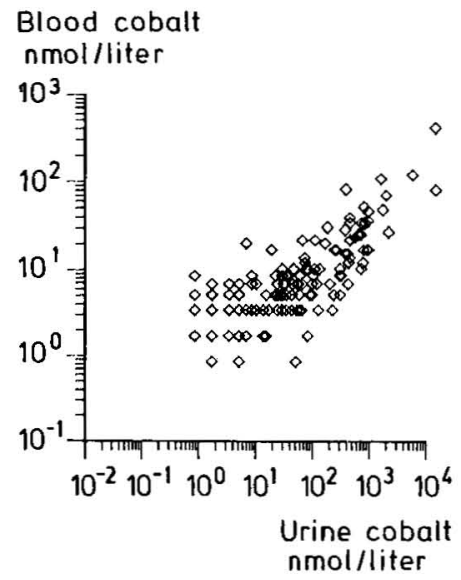

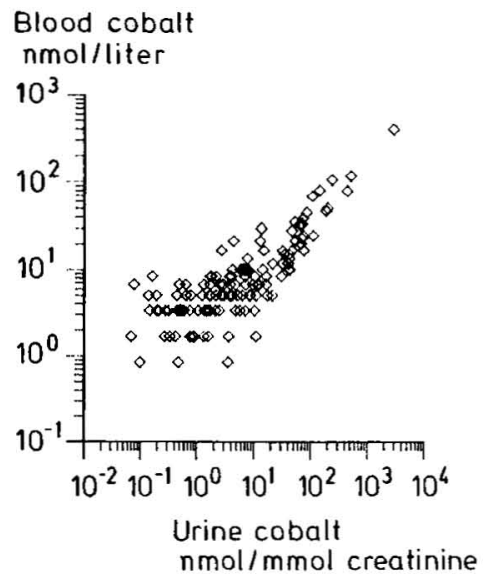

Figure 2. Relation between the blood and urine cobalt concentrations. Left figure without correction for the concentration of creatinine in urine (Pearson's correlation coefficient $=0.77$ ). Right figure with correction for creatinine in urine (Pearson's correlation coefficient $=0.82$ ) . 
Table 2. Estimates $(\hat{\beta})$ and standard error (SE) of the effect of plate painting on lung function corrected for age and height. Measurements from the first examination of the plate painters after approximately six weeks off work, compared with measurements for the referents.

\begin{tabular}{|c|c|c|c|c|c|c|}
\hline \multirow{3}{*}{ Lung function variable } & \multicolumn{4}{|c|}{ Effects of plate painting } & \multirow{2}{*}{\multicolumn{2}{|c|}{$\begin{array}{c}\text { Difference in the effect of } \\
\text { plate painting for smokers } \\
\text { and nonsmokers }\end{array}$}} \\
\hline & \multicolumn{2}{|c|}{ Nonsmokers } & \multicolumn{2}{|c|}{ Smokers } & & \\
\hline & $\hat{\beta}$ & SE & $\hat{\beta}$ & SE & $\hat{\beta}$ & SE \\
\hline Vital capacity & -0.17 & 0.15 & 0.02 & 0.15 & -0.20 & 0.21 \\
\hline Total lung capacity & -0.23 & 0.17 & 0.16 & 0.18 & -0.39 & 0.25 \\
\hline Residual volume & 0.12 & 0.11 & 0.12 & 0.11 & -0.01 & 0.16 \\
\hline Residual volume/total lung capacity & $0.04^{*}$ & 0.02 & 0.01 & 0.02 & 0.02 & 0.03 \\
\hline Peak expiratory flow & $-0.93^{*}$ & 0.38 & $-1.14^{\star}$ & 0.39 & 0.20 & 0.54 \\
\hline Forced expiratory volume in $1 \mathrm{~s}$ & $-0.48^{* *}$ & 0.14 & -0.20 & 0.15 & -0.28 & 0.20 \\
\hline $\begin{array}{l}\text { Forced expiratory flow rate at } 50 \% \\
\text { of vital capacity }\end{array}$ & $-0.70^{\star}$ & 0.31 & -0.14 & 0.32 & -0.56 & 0.44 \\
\hline $\begin{array}{l}\text { Forced expiratory flow rate at } 25 \% \\
\text { of vital capacity }\end{array}$ & $-0.70^{\star \star}$ & 0.25 & 0.15 & 0.25 & $-0.85^{\star}$ & 0.35 \\
\hline Slope index & 0.09 & 0.06 & 0.04 & 0.06 & 0.04 & 0.09 \\
\hline Wash-out volume & 0.03 & 0.04 & $0.12^{*}$ & 0.04 & -0.10 & 0.06 \\
\hline Transfer factor & -0.008 & 0.006 & 0.003 & 0.006 & -0.010 & 0.009 \\
\hline
\end{tabular}

${ }^{*} P<0.05,{ }^{* *} P<0.01$.

were replaced in the statistical analysis by a value of $0.85 \mathrm{nmol} / 1$. Figure 1 shows the distribution of cobalt in the blood and urine of the workers. Summary statistics are shown in table 1. The first examination took place when the plate painters had been workfree for a median of $41(\mathrm{SD}=43) \mathrm{d}$. The second examination took place at a median of $29(\mathrm{SD}=14) \mathrm{d}$ after they had resumed work. In the first examination the mean blood level of the plate painters was twice as high as that of the referents, and the urinary cobalt levels were five to six times higher. In the second examination the cobalt concentration in blood was nine times higher among the plate painters and the corresponding urine concentrations were $85-90$ times higher. We found no significant correlation between the concentration of cobalt in blood or urine and the duration of employment as a plate painter, nor were smoking habits significantly related to the cobalt concentrations in the blood or urine.

The correlation between the cobalt concentrations in the blood and urine is shown in figure 2 . The tightest correlation was obtained for high cobalt concentrations after correction for the creatinine concentration of the urine.

\section{Lung function tests}

The results of the lung function tests in the first examination of the plate painters have been related to the results of the referents and the status of smoking within both groups (table 2).

The pattern of lung function changes among the nonsmoking and smoking plate painters indicated obstruction for both groups, but the changes seemed more pronounced for the nonsmokers, especially for
Table 3. Changes in the lung function of the plate painters approximately four weeks after they resumed work after approximately six weeks of being off work. (Value of the second examination minus the value of the first examination.)

\begin{tabular}{lcc}
\hline \multirow{2}{*}{ Lung function variable } & \multicolumn{2}{c}{ Mean difference } \\
\cline { 2 - 3 } & $\hat{\beta}$ & SE \\
\hline Vital capacity & -0.06 & 0.05 \\
Total lung capacity & -0.05 & 0.06 \\
Residual volume & -0.03 & 0.04 \\
Residual volume/total lung capacity & -0.002 & 0.006 \\
Peak expiratory flow & $0.55^{\star *}$ & 0.15 \\
Forced expiratory flow in 1 s & $0.11^{\star \star}$ & 0.04 \\
Forced expiratory flow rate at 50\% & & \\
of vital capacity & $-0.35^{\star \star}$ & 0.07 \\
Forced expiratory flow rate at $25 \%$ & & \\
of vital capacity & $-0.38^{\star *}$ & 0.08 \\
Slope index & $0.04^{*}$ & 0.02 \\
Nitrogen washout volume & -0.018 & 0.014 \\
Transfer factor & $-0.008^{\star *}$ & 0.002 \\
\hline
\end{tabular}

${ }^{*} \mathrm{P}<0.05,{ }^{* *} \mathrm{P}<0.01$.

$\mathrm{MEF}_{25}$ and $\mathrm{MEF}_{50}$. However, the differences between the two groups were significant only for $\mathrm{MEF}_{25}$. If the change in lung function was estimated for the two groups together, any possible interaction between smoking and cobalt exposure being disregarded, plate painters were found to have a significantly higher residual volume and nitrogen washout volume and a significantly lower PEF and $\mathrm{FEV}_{1.0}$, whereas the lower $\mathrm{MEF}_{50}$ value was not significant $(\mathrm{P}<0.10)$.

Table 3 shows the difference in the lung function tests of the plate painters in the two examinations. The $\mathrm{PEF}$ and $\mathrm{FEV}_{1.0}$ increased significantly from the first to the second examination, and the $\mathrm{MEF}_{50}$ and $\mathrm{MEF}_{25}$ 
decreased significantly. The correlation coefficients between the changes in $\mathrm{MEF}_{50}$ and $\mathrm{MEF}_{25}$ and changes in PEF and $\mathrm{FEV}_{1.0}$ were positive and nonsignificant. The decrease in $\mathrm{MEF}_{50}$ and $\mathrm{MEF}_{25}$, therefore, was not secondary to the increase in PEF and FEV ${ }_{1.0}$. The slope index increased significantly and the transfer factor decreased significantly after work was resumed. The changes in the lung function variables were not associated with the height, smoking, or cobalt exposure indices.

The effects of stimulation with salbutamol showed no obvious pattern and no significant differences between the plate painters and the referents or between the plate painters in the first and second examinations.

\section{Clinical examination}

There was no significant difference between the two groups, or between the first and second examination of the plate painters, regarding redness or irritation of the mucous membranes or skin, auscultation of the heart and lungs, or abnormalities of the thyroid gland.

The electrocardiograms showed few abnormalities, and no differences between the two groups were found, except that pulse rate was significantly higher for the plate painters than for the referents. This difference was 10.3 [standard error (SE) 2.5] beats per minute in the first examination and 6.2 (SE 2.3) beats per minute in the second examination. The difference between the first and second examinations of the plate painters was not significant. The difference in pulse rate between the two groups was not explained by differences in smoking habits. The pulse rate was not associated with the cobalt levels in the blood or urine.

There were no significant differences in blood pressure between the plate painters and referents or between the plate painters in the first and second examinations.

The results of the hematological examination showed only small and nonsignificant differences between the plate painters in the first examination and the referents. In the second examination of the plate painters, the hematocrit decreased from 0.41 to 0.40 , and the mean cell volume decreased from 93.2 to $92.0 \mathrm{fl}$. These small changes, however, were significant $(\mathrm{P}<0.01)$. The hemoglobin and erythrocyte levels tended to decrease, and the mean cell hemoglobin concentration tended to increase $(0.07<P<0.12)$, but these changes were also very small. The changes did not correlate with smoking or with the changes in the concentration of cobalt in the blood or urine.

The examination of the urine for blood, glucose, and protein showed only few abnormalities, and no differences between the two groups.

\section{Discussion}

For nearly 100 years cobalt blue has been used as an underglaze color in the Danish manufacture of plates
(22). However, with the exception of skin injuries (15), health effects in the porcelain industry following exposure to cobalt have never been reported. Most of the studies concerning health effects following occupational exposure to cobalt have dealt with conditions in the hard metal industry $(6,9,13)$. The studies of Alexandersson et al (2-8) of workers in the Swedish hard metal industry are the only ones to relate health effects to both the concentration of airborne cobalt and cobalt levels in the blood and urine. Like our study, their study was a cross-sectional investigation of workers who were fit for work. For this reason, both of the studies may underestimate work-related health effects. However, the participants in our study had a mean duration of employment of $11-14$ years, indicating a low turnover rate.

Seven months before we performed our investigation, the median concentration of airborne cobalt in the breathing zones of the plate painters was 16 times the Danish occupational exposure limit for cobalt $(0.05$ $\left.\mathrm{mg} / \mathrm{m}^{3}\right)$. There are reasons to assume that the concentration of airborne cobalt was much lower at the time of our study since some work conditions had been changed and the fume cupboards adjusted, and measurements made by the factory one month after the end of the study showed airborne cobalt levels just around the Danish occupational exposure limit. Hence the results of the first examination may reflect chronic or subchronic effects of exposure to the previous very high levels of airborne cobalt, and the results of the second examination may reflect acute effects of cobalt at airborne concentrations of around $0.05 \mathrm{mg} / \mathrm{m}^{3}$.

To relate the possible effects to cobalt exposure, we measured the cobalt levels in the blood and urine of the workers. The plate painters, after six weeks without cobalt exposure, had a mean blood cobalt concentration that was two times higher than that of the referents. Their mean value for cobalt in urine was five to six times higher. After the women resumed work, their mean blood cobalt concentration increased to nine times that of the referents, and their mean urine cobalt concentration to $85-90$ times that of the referents. In the study of Alexandersson et al (8) the mean concentration of cobalt in the blood of five workers exposed to an airborne cobalt level of $0.09 \mathrm{mg} / \mathrm{m}^{3}$ was 178.1 (SD 184.9) $\mathrm{nmol} / \mathrm{l}$. In our study, the mean concentration of cobalt in the blood of the plate painters after they resumed work, and with exposure to an airborne cobalt concentration of approximately $0.05 \mathrm{mg} / \mathrm{m}^{3}$, was 36.7 (SD 63.2) nmol/1. Both studies reported the same correlation coefficient of 0.82 between cobalt in blood and urine.

The plate painters complained of more symptoms of irritation of the respiratory tract than did the referents, and these symptoms increased after the women resumed work. These findings are in accordance with those of Alexandersson et al (2). 
After six weeks off work the airflow parameters, adjusted for effects of smoking, were lower for the plate painters than for the referents. Since the lung function changes were not related to the cobalt concentrations in the blood or urine, the difference between the plate painters and referents cannot be ascribed to an acute effect of the cobalt remaining in the body after six weeks without exposure. Unfortunately, it was not possible to establish estimates of previous cobalt exposure for each of the plate painters, and, consequently, dose-response associations could not be examined. The finding that lung function parameters were not related to the duration of employment as a plate painter should not be taken as evidence against dose-response relations. The big variation between plate painters with respect to blood and urine cobalt concentrations after the resumption of work clearly suggests that estimates of accumulated exposure over time may be only weakly, if at all, associated with duration of employment. Since there was no difference between the plate painters and the referents with respect to the effects of salbutamol stimulation, the signs of increased obstruction in the plate painters cannot be explained by a bronchospastic condition. In conclusion, the findings suggest that a chronic or subchronic obstructive lung function impairment may result from previously very high levels of airborne cobalt. However, we cannot exclude that these findings may be due to other constituents of the dye or to a nonspecific effect of high levels of dust or droplet aerosols of the dye.

After the women resumed work, the $\mathrm{FEV}_{1.0}$ and $\mathrm{PEF}$ values increased, a finding that we consider to be due to a training effect. $\mathrm{MEF}_{50}$ and $\mathrm{MEF}_{25}$ decreased, and this change was not associated with the improvement in $\mathrm{FEV}_{1.0}$ or PEF. The change in the MEF values, therefore, may be interpreted as an acute effect of plate painting. The changes in the MEF values were not associated with changes in the blood or urinary cobalt levels. This finding suggests that the acute effect of plate painting on small airway functioning may be due to a local effect of inhaled dust or droplet aerosols in the bronchioli. Since there was no difference between the effect of salbutamol stimulation in the first and second examinations of the plate painters, the acute effect of plate painting on small airway functioning cannot be ascribed to a bronchospastic condition. This result is different from those of Roto (20) in his study of asthma among cobalt and zinc production workers. Our results of the acute effects of plate painting may be explained by swelling of the mucosa in the bronchioli because of an irritating effect of dust or droplet aerosols. Whether cobalt has any specific effect in this context seems uncertain.

Alexandersson et al (3) examined five groups of hard metal workers who had been exposed to different levels of cobalt and found impaired pulmonary function among the moderately and highly exposed employees at the end of the week. Only in the most heavily ex- posed group, with an average cobalt exposure of 0.06 $\mathrm{mg} / \mathrm{m}^{3}$, was a persisting reduction in lung function, mainly of the obstructive type, found after the weekend. This reduction, moreover, remained after four weeks of vacation. They concluded that for the most exposed subjects a chronic reduction in lung function could not be excluded. We reach the same conclusion in our study. The results of the two studies indicate that cobalt may cause the same kind of lung damage whether it is inhaled as a metal or as salt dust. Experimental studies on minature swine support these findings (17).

In excessive quantities, cobalt is a known myocardial poison $(9,10,12,16)$. Alexandersson et al $(4,5)$ examined heart function and found small electrocardiographic changes among wet grinders exposed to a cobalt concentration of $0.01 \mathrm{mg} / \mathrm{m}^{3}$. The frequency of the changes decreased significantly after a four-week vacation. The pulse rate was not reported as being related to cobalt exposure. In our study, we found that the only effect on heart function was a significantly higher pulse rate in the plate group than in the reference group. This difference was not explained by the difference in smoking habits, and it was not related to the cobalt concentration in the blood urine. We have no explanations for this finding.

Cobalt stimulates the formation of red blood cells (23) and was previously used in the treatment of anemia. In our study, we found no difference in the red blood cell volume between the plate painters and the referents. The small changes in the plate painters after their resumption of work are difficult to interpret, but they may possibly reflect a rebound phenomenon owing to the previous very high level of cobalt exposure.

The most notable findings in our study were the high cobalt levels in the blood and urine of the plate painters after a few weeks of work, even though technical precautions had decreased the exposure level of cobalt to the Danish occupational exposure limit.

It is also remarkable that increased cobalt concentrations were still found in the urine and blood after six weeks of absence from work.

Considering the toxicity of cobalt, including its possible carcinogenic effect (14), these results must give rise to considerable concern.

\section{Acknowledgments}

This study was supported by the Danish Work Environment Fund, grant 1979-36.

\section{References}

1. Åstrand I, Areskog N-H, Carlsten A, Gerwin K-E, Kaijser L, Malström G, Punsar S, Blomqvist G, Bjerkelund C, Furberg C, Hansen F, Kallio V, Nordgren L, Pyörälä $\mathrm{K}$, Thulesius O. The "Minnesota Code" for ECG clas- 
sification: Adaption to CR leads and modification of the code for ECGs recorded during and after exercise. Acta Med Scand Suppl 481 (1967).

2. Alexandersson R. Undersökningar över effekter av exposition för kobolt: II Reaktioner $i$ andningsorganen vid olika grad av exposition i hårdmetallindustrien [Studies on effects of exposure to cobalt: II Pulmonary reactions to various degrees of exposure in the hard metal industry]. Arbetarskydssverket, Stockholm 1978. (Arbete och hälsa 1979: 2).

3. Alexandersson R. Undersökningar över effekter av exposition för kobolt: VI Exposition upptag och lungpåverkan av kobolt $\mathbf{i}$ hårdmetallindustri [Studies on effects of exposure to cobalt: VI Exposure, uptake and lung function in Swedish hardmetal industry]. Arbetarskyddsverket, Stockholm 1979. (Arbete och hälsa 1979: 10).

4. Alexandersson R, Atterhog J. Undersökningar över effekter av exposition för kobolt: VII Hjärteeffekter av exposition i svensk hårdmetallindustri [Studies on effects of exposure to cobalt: VII Heart effects of exposure to cobalt in Swedish hardmetal industry]. Arbetarskyddsverket, Stockholm 1980. (Arbete och hälsa 1980: 9).

5. Alexandersson R, Atterhög J. EKG-förändringar hos koboltexponerade våtslipare före och efter arbetusupphåll [Comparison of electrocardiograms among wet grinders in Swedish hard metal industry before and after four weeks holiday]. Arbetarskyddsverket, Stockholm 1983. (Arbete och hälsa 1983: 18).

6. Alexandersson R, Bergman K. Undersökningar över effekter av exposition för kobolt: I Undersökning över expositionsförhållandena $\mathrm{i}$ hårdmetallindustrin [Studies on effects of exposure to cobalt: I Study on the exposure in the hardmetal industry]. Arbetarskyddsverket, Stockholm 1978. (Arbete och hälsa 1978: 20).

7. Alexandersson R, Hedenstierna G. Undersökningar över effekter av exposition för kobolt: III Ventilationsformåga, distribution av indandingsgas och luftvägsavstängning under pågående arbete och efter expositionssuppehåll [Studies on effects of exposure to cobalt: III Ventilatory capacity, distribution of inspired air and airway closure during work and after a period without work]. Arbetarskyddsverket, Stockholm 1979. (Arbete och hälsa 1979: 7).

8. Alexandersson R, Vitauts L. Undersökningar över effekter av exposition för kobolt: IV Koboltkoncentrationen i blod och urin som expositionsindikator [Studies on effects of exposure to cobalt: IV Cobalt concentrations in blood and urin as an exposure indicator]. Arbetarskyddsverket, Stockholm 1979. (Arbete och hälsa 1979: 8)

9. Baborik M, Dusek J. Cardiomyopathy accompanying industrial cobalt exposure. Br Heart J 34 (1972) 113116.

10. Bonenfant JL, Miller G, Roy PE. Quebec beer-drinkers' cardiomyopathy: Pathological studies. Can Med Assoc J 97 (1967) 910-916.

11. Christensen JM, Mikkelsen S, Skov A. Direct determination of cobalt in blood and urine by Zeeman atomic absorption spectrophotometer. In: Brown SS, Savory $\mathrm{J}$, ed. Clinical toxicology and clinical chemistry of metals. Academic Press, London 1983, pp 65-68.

12. Elinder C, Friberg L. Cobalt. In: Friberg L, Nordberg GF, Vouk VB, ed. Handbook on the toxicology of metals. Elsevier/North-Holland Biomedical Press, Amsterdam, New York, Oxford 1979, pp 399-410.

13. Fischer T, Rysted I. Cobalt allergy in hard metal workers. Contact Dermatitis 9 (1983) 115-121.

14. Gilman JPW. Metal carcinogenesis: Il A study on the carcinogenic activity of cobalt, cobber and nickel compounds. Cancer Res 22 (1962) 158-162.

15. Keiding LM. Arbejdsrelaterede hudlidelser på en keramisk virksomhed [Work related skin conditions at a ceramic industry]. Ugeskr Laeg 14 (1979) 2335-2340.

16. Kennedy A, King R, Dornan JD. Fatal myocardial disease associated with industrial exposure to cobalt. Lancet 2 (1981) $412-424$.

17. Kerfoot EJ, Fredrick WG, Domeir E. Cobalt metal inhalation studies on minature swine. Am Ind Hyg Assoc J 1 (1975) 17-25.

18. Ostaczup P, Valenta P, Stoeppler M, Nürnberg HW. Voltametric determination of nickel and cobalt in body fluid and other biological materials. In: Brown SS, Savory $\mathrm{J}$, ed. Chemical toxicology and clinical chemistry of metals. Academic Press, London 1983, pp 61-64.

19. Quanjer ED. Standardized lung function testing. Bull Eur Physiopathol Respir 19 (1983): suppl 5, 1-97.

20. Roto P. Asthma, symptoms of chronic bronchitis and ventilatory capacity among cobalt and zinc production workers. Scand J Work Environ Health 6 (1980): suppl 1, 49 p.

21. Suvorov IM, Cekunova MP. Cobalt, alloys and compounds. In: Parmeggiani L, ed. Encyclopaedia of occupational health and safety. Third edition. International Labour Office, Geneva 1983.

22. Royal Copenhagen Porcelain Manufactory Ltd. Plates from the Royal Copenhagen Manufactory. Nordisk Forlag A/S, Copenhagen 1970.

23. Van Wolters HG. Zur wirkung von Kobalt aus die Erythropoese. Blut 21 (1970) 105-117.

Received for publication: 3 April 1987 